\title{
Wykorzystanie źródeł laserowych led do spajania cienkościennych elementów z blach nierdzewnych
}

\author{
Use of laser led sources for welding of thin wall \\ workpieces from stainless steel sheets
}

\section{Streszczenie}

W artykule scharakteryzowano metodę spawania laserowego dla elementów cienkościennych wykonanych z blach nierdzewnych. Wymieniono wady i zalety procesu oraz praktyczne przykłady zastosowania.

Słowa kluczowe: spawanie laserowe; cienkościenne blachy nierdzewne

\begin{abstract}
In the article the method of welding of thin wall workpieces made from stainless steel sheets was characterised. The advantages and disadvantages of the process and examples of practical application are listed.
\end{abstract}

Keywords: laser welding; thin wall stainless steel sheets

\section{Wstęp}

Procesy spawalnicze są najbardziej rozwiniętą i ugruntowaną technologią łączenia elementów, powszechnie wykorzystywaną przy wytwarzaniu wyrobów metalowych, w tym ze stali nierdzewnych. Proces spawania charakteryzuje się wieloma specyficznymi cechami, związanymi głównie ze zmiennym polem temperatur oraz ze zmieniającymi się właściwościami fizycznymi i mechanicznymi łączonego materiału

Zjawiska zachodzące $\mathrm{w}$ procesie spawania wchodzą w zakres wielu dziedzin wiedzy i rozwijane były często niezależnie od siebie, m.in. w odlewnictwie, metaloznawstwie i mechanice. Masowe stosowanie spawania, datujące się od czasów II wojny światowej, wywołało potrzebę całościowej analizy tego procesu, niezależnie od innych technik oraz jego wpływu na właściwości, nie tylko samych złączy spawanych, ale i całych konstrukcji. Specyficzny charakter tworzenia struktury strefy wpływu ciepła połączenia, uwarunkowany cyklem cieplnym spawania, powoduje powstanie struktur o dużej różnorodności. W związku z tym opracowanie optymalnej technologii spawania powinno być oparte o precyzyjną analizę zjawisk zachodzących w procesie spawania a przede wszystkim: skłonności do przemian struktury austenitu w warunkach spawania, podatność do tworzenia różnego rodzaju pęknięć, jak również właściwości użytkowych i estetycznych złącza spawanego. Znajomość różnych, powszechnie dostępnych metod spawalniczych, pozwala na optymalne dobranie procesu łączenia konkretnych części w zależności od charakteru produkcji.

\section{Nowoczesne technologie w spawalnictwie}

Spawanie laserowe polega na stapianiu obszaru styku wiązką promieni spolaryzowanych. Proces prowadzony jest w osłonie gazów obojętnych, zapewniając dużą wytrzymałość spoin. Powszechnie stosowane jest w produkcji wielkoseryjnej, np. w przemyśle motoryzacyjnym. Spawanie laserowe wykorzystuje wiązkę o dużej gęstości energii, w wyniku czego otrzymuje się małą szerokość strefy wpływu ciepła (SWC), a tym samym niskie oddziaływanie temperatury na konstrukcję, szybkie odprowadzanie ciepła i stygnięcie spoiny. Możliwa do uzyskania szerokość spoin zawiera się w przedziale od 0,2 do $13 \mathrm{~mm}$. W praktyce wykorzystywane są głównie spoiny o małych szerokościach. Głębokość przetapiania materiału promieniem lasera jest proporcjonalna do energii zasilania oraz lokalizacji punktu skupienia wiązki. Największe przenikanie wiązki uzyskuje się, gdy punkt skupienia znajduje się nieco poniżej powierzchni łączonych materiałów. Spawanie laserowe stosowane jest do łączenia elementów ze stali, a także aluminium i tytanu. Promieniem lasera można łączyć przedmioty obrabiane powierzchniowo lub wykonywać głębokie połączenia zgrzewane. Można łączyć go z konwencjonalnymi metodami spawania, w tym z lutowaniem [1]. Laserem można spawać zarówno materiały o wysokiej temperaturze topnienia, jak i o wysokiej przewodności cieplnej. Ze względu na niewielki obszar oraz krótki, sterowalny czas topienia, łączy się nawet część tworzyw, które zwykle nie poddają się spawaniu. Nawet podczas liniowego spawania laserami z ciągłą emisją promieni, strefa oddziaływania wysokiej temperatury oraz całkowite rozgrzanie elementu są wciąż o wiele mniejsze, niż podczas spawania łukowego lub plazmowego. Dopływ energii można bardzo dobrze monitorować, regulować i utrzymywać na stałym poziomie lub precyzyjnie nim sterować. Spawanie laserowe umożliwia łączenie pojedynczymi impulsami lasera lub w trybie ciągłym. Różne rodzaje połączeń wymagają odpowiednich trybów pracy źródła promieniowania laserowego.

Dr hab. inż. Tadeusz Sałaciński, prof. PW - Politechnika Warszawska; mgr inż. Wojciech Sosnowski - Prod-Met Sp. z o.o. Autor korespondencyjny/Corresponding author. wojtek.sosnowski@o2.pl 
Zalety spawania laserowego [2] (LBW - Laser Beam WeIding) wynikają z zalet związanych z generowaniem dużej energii połączone $z$ jej skupieniem na odpowiednio małej powierzchni. Wielkość przetopu łączonych elementów jest zależna od ilości dostarczonej energii oraz od usytuowania punktu zogniskowania wiązki. Jak pokazuje doświadczenie, pełny przetop osiąga się, gdy ognisko (fokusowanie) usytuowane jest poniżej powierzchni łączonych elementów. Coraz częściej stosowane jest hybrydowe łączenie detali przy użyciu lasera (HLAW - Hybrid Laser Arc Welding). Polega ono na połączeniu cech spawania laserowego, np. z metodami MIG/MAG. Wykorzystanie właściwości obu metod pozwala na dokładne wypełnienie szczeliny między łączonymi elementami, zachowując jednocześnie dużą prędkość procesu charakterystyczną dla spawania laserowego. Wykonane $w$ ten sposób złącza mają bardzo dobre parametry ze względu na małą strefę wpływu ciepła oraz głęboką penetrację łączonych części. Spawanie metodami hybrydowymi jest znacznie szybsze od tradycyjnych metod łukowych i pozwala zaoszczędzić w niektórych przypadkach nawet do $80 \%$ czasu spawania.

Stosując lasery wysokiej mocy, można łączyć elementy stalowe do $20 \mathrm{~mm}$ grubości za jednym przejściem, co znacząco zwiększa wydajność procesu. Dodatkowo technologia ta umożliwia monitorowanie procesu w czasie rzeczywistym, co pozwala na modyfikowanie parametrów zależnie $\mathrm{np}$. od zmian odległości łączonych przedmiotów.

\section{Zalety spawania laserowego}

Do głównych zalet spawania laserowego należy zaliczyć:

- wąską strefę wpływu ciepła minimalizującą odkształcenia materiału,

- wysoką precyzję zapewniającą estetykę spoiny (eliminacja obróbki wykończeniowej),

- wysoką prędkość i czystość procesu,

- doskonałe wyniki spawania aluminium i stali kwasoodpornej oraz materiałów trudno spawalnych,

- wysoką gęstość mocy (spawanie typu kapilarnego),

- spawanie bez materiału dodatkowego,

- możliwość łączenia z innymi metodami spawania,

- automatyzację - większa efektywność.

\section{Wady spawania laserowego}

Do głównych wad spawania laserowego należy zaliczyć:

- nieopłacalność przy produkcji jednostkowej,

- detale przygotowane do spawania laserowego muszą być przygotowane z odpowiednią dokładnością (teoretycznie $+/-0,1 \mathrm{~mm}$ ),

- do połączenia kilku elementów w jeden wymagane jest zamocowanie ich na stole roboczym robota,

- niezbędne staje się wytworzenie specjalnego przyrządu do tego celu. Koszt takiego przyrządu to w zależności od skomplikowania detalu od kilku do kilkunastu tysięcy złotych.

\section{Przykłady wykorzystania spawania laserowego}

Spawanie laserowe wykorzystuje się w następujących obszarach przemysłowych:

- w produkcji pojazdów i części (w tym lotniczych), zbiorników, sprzętu AGD,
- budowie maszyn,

- klimatyzacji i wentylacji,

- energetyce i elektronice,

- technice medycznej.

Obecnie również przy produkcji artykułów gospodarstwa domowego spawanie laserowe jest stosowane na szeroką skalę przy łączeniu wielu elementów. Podstawowymi zaletami, dzięki którym spawanie laserowe znalazło swoje zastosowanie przy produkcji AGD są:

- proces odbywa się bezkontaktowo,

- duża wytrzymałość komponentów,

- krótki czas cyklu,

- redukcja wpływu ciepła oraz odkształceń,

- elastyczność sieci laserowej i światłowodu,

- duża wydajność i redukcja kosztów.

\section{Lasery stosowane do spawania}

Proces spawania prowadzi się na dwa sposoby. Pierwszy, w przypadku spawania laserami Nd:YAG oraz diodowymi małej mocy, charakteryzuje się nagrzewaniem powierzchni łączonych części oraz wnikaniem ciepła w głąb dzięki przewodności cieplnej materiału. Drugi - spawanie z głębokim wtopieniem, wykonuje się przede wszystkim laserami $\mathrm{CO}_{2}$ oraz $\mathrm{Nd}$ :YAG dużej mocy. Skupienie energii wiązki laserowej prowadzi do powstania kanału gazodynamicznego, co ułatwia wnikanie energii lasera głęboko w materiał. Wykonane w ten sposób połączenia charakteryzuje wysoki poziom smukłości.

Wybór gazu osłonowego należy uzależnić nie tylko od rodzaju i grubości łączonych materiałów, ale także od typu zastosowanego lasera. Hel jako gaz osłonowy charakteryzuje się szczególną uniwersalnością, jednak często z powodzeniem można również stosować argon. Zastosowanie mieszanek wieloskładnikowych, na bazie helu oraz argonu wraz z domieszką innych gazów, pozwala, obok zmian zasadniczych parametrów procesu (mocy wiązki, prędkości, ogniskowania wiązki) na dodatkową modyfikację własności spoiny [3].

W laserach gazowych $\mathrm{CO}_{2}$ ośrodkiem czynnym jest mieszanina gazów składająca się z helu, azotu i $\mathrm{CO}_{2}$. Mogą one pracować w sposób ciągły lub impulsowy. Emitują światło o długości fali 10,6 $\mu \mathrm{m}$ i mają sprawność ok. 10-15\%. Aby utrzymać wymaganą sprawność, mieszanina gazów znajdująca się $\mathrm{w}$ rezonatorze musi być ciągle chłodzona i regenerowana. W tym celu stosuje się zamknięty, wymuszony przepływ gazów obejmujący: rezonator, wymiennik ciepła i regenerator. Sposób przepływu gazów przez rezonator istotnie wpływa na jakość wiązki laserowej.

Wykorzystywane aktualnie w technologii łączenia materiałów lasery $\mathrm{CO}_{2}$ są laserami o przepływie gazów osiowym bądź prostopadłym w stosunku do osi rezonatora. W laserach o przepływie osiowym szybkim mieszanina gazów przemieszcza się wzdłuż osi rezonatora z prędkością ok. $500 \mathrm{~m} / \mathrm{s}$. Tego typu lasery tworzą wiązkę o modzie toroidalnym TEM*01 pozwalającą uzyskać wysoką jakość spawania. Aktualnie tego typu lasery mogą osiągać moc dochodzącą do $20 \mathrm{~kW}$. W laserach o przepływie poprzecznym mieszanina gazów przepływa ze względnie małymi prędkościami przez rezonator, prostopadle do jego osi. Z uwagi na możliwość znacznego powiększania mocy optycznej wiązki w rezonatorze, moc tych laserów, w zależności od konstrukcji, może kilkakrotnie przekroczyć moc uzyskiwaną przez lasery o podłużnym przepływie. Z uwagi jednak na wielomodowość generowanej wiązki, jakość wykonanych spoin będzie niższa. 
W laserach stałych Nd:Yag ośrodek czynny stanowi pręt wykonany z granatu itrowo - aluminiowego z domieszką jonów neodymu Nd3+. Emitują one światło o długości fali $1,06 \mu \mathrm{m}$. Główną ich zaletą, w porównaniu do laserów $\mathrm{CO}_{2}$, jest to, że promień lasera może być przenoszony światłowodami, co znacznie ułatwia montaż tych urządzeń w systemach produkcyjnych. Z uwagi jednak na bardzo małą sprawność wynoszącą 2-5\%, małe generowane moce i pracę w trybie impulsowym, lasery te aż do początku lat 90. ubiegłego wieku miały dosyć ograniczone pole zastosowań. Obecnie, dzięki znacznym dokonanym udoskonaleniom, dostępne są lasery, które przy mocy dochodzącej do 5 kW mogą być użyte do spawania ciągłego głębokiego. Zaletą wiązki lasera $\mathrm{Nd}$ :Yag, w porównaniu do wiązki lasera $\mathrm{CO}_{2}$, jest krótsza długość fali (lepsza pochłanialność przez metale), brak oddziaływania z plazmą spawalniczą. Wadą jej jest wielomodowość pojawiająca się w wyższych zakresach mocy ze względu na obecność procesów cieplno-naprężeniowych wewnątrz prętów emitujących promieniowanie [4].

Rodzaje źródła laserów:

a) gazowe,

b) oparte na ciele stałym:

- prętowe,

- dyskowe,

- włóknowe,

- diodowe (najnowsze rozwiązanie).

Obecnie przy spawaniu laserowym najpowszechniej stosuje się źródła gazowe i rezonatory dyskowe. Zasadniczą różnicą jest długość fali wiązki lasera:

- dyskowe (Nd: YAG - fiber) posiadają - 1,06 $\mu \mathrm{m}$

- gazowe $\left(\mathrm{CO}_{2}\right)$ - 10,6 $\mu \mathrm{m}$

Odbita wiązka o długości fali $1,06 \mu \mathrm{m}$ jest bardzo niebezpieczna dla ludzkiego wzroku. Dlatego zachowanie bezpieczeństwa, czyli odizolowanie procesu od otoczenia, jest wymogiem bezwzględnym przy zastosowaniu rozwiązania w oparciu o rozwiązanie na ciele stałym.

\section{Wybrane metody spawania z wykorzystaniem promieni lasera}

W procesie spawania z głębokim wtopieniem [5] niezbędne są bardzo wysokie skupienia mocy rzędu ok. $1 \mathrm{MW} /$ $\mathrm{cm}^{2}$. Wówczas promień lasera nie tylko topi metal, lecz powoduje także jego parowanie. Podczas parowania, na roztopiony materiał działa ciśnienie i częściowo go wypiera. Przedmiot obrabiany ulega jeszcze głębszemu stopieniu. Powstaje głęboki, wąski, wypełniony parą otwór: kapilara wypełniona parą - zwana również Keyhole (angielski odpowiednik dziurki od klucza). Wypełniona parą kapilara otoczona jest roztopionym materiałem. Gdy laser przesunie się po łączeniu na przedmiocie obrabianym, wraz z nim przesuwa się także kapilara. Roztopiony metal opływa kapilarę i zastyga za nią.

W ten sposób tworzy się wąska, głęboka spoina o równomiernej strukturze. Głębokość spojenia jest do 10 razy większa od jego szerokości i może wynosić nawet $25 \mathrm{~mm}$. $\mathrm{Na}$ ściankach kapilary z roztopionym, płynnym materiałem, promień lasera ulega wielokrotnemu odbiciu. Roztopiony materiał niemal całkowicie absorbuje promień lasera prowadząc do wzrostu skuteczności procesu spawania. Podczas spawania laserami $\mathrm{CO}_{2}$ para w kapilarze również absorbuje światło lasera i ulega częściowej jonizacji. Powstaje plazma, która dodatkowo dostarcza energię do przedmiotu obrabianego. Dlatego spawanie z głębokim wtopieniem cechuje się wysoką skutecznością oraz dużymi prędkościami spawania. Dzięki dużej prędkości obróbki, strefa oddziaływania wysokiej temperatury jest mała, a odkształcenie nieznaczne. Metoda jest stosowana tam, gdzie wymagane są duże głębokości spawania lub jednoczesne zgrzewanie kilku warstw materiału.

Spawanie skanujące [6] umożliwia projektowanie wysoce produktywnych i elastycznych maszyn, które szybciej, precyzyjniej i tym samym ekonomiczniej wykonują operacje spawania $w$ produkcji seryjnej, niż ma to miejsce w standardowych metodach spawania. Podczas spawania skanującego, promień lasera jest prowadzony przez ruchome zwierciadła. Zmiany ustawienia kątowego zwierciadeł przekierowują promień lasera. Powstaje obszar obróbki, na którym można spawać z dużą dynamiką i precyzją. Wielkość tego obszaru zależy od odstępu roboczego i kąta odbicia.

Prędkość obróbki oraz średnica ogniskowej na przedmiocie obrabianym zależy od właściwości odzwierciedlających układu optycznego, kąta padania promienia, jakości promienia oraz materiału. Bardzo szybkie przesuwy niemal całkowicie eliminują czasy pomocnicze, dzięki czemu agregat laserowy może produkować przez prawie $100 \%$ czasu produkcji.

Podczas spawania kondukcyjnego [7] promień lasera roztapia elementy wzdłuż miejsca łączenia. Roztopione materiały przenikają się i zastygają, tworząc spoinę. Spawanie kondukcyjne stosuje się do łączenia elementów cienkościennych, na przykład narożników na widocznych krawędziach sprzętu AGD takich jak: obudowy okapów kuchennych (rys. 1), lodówek itp. Pozostałe zastosowania dotyczą elektroniki. Laser tworzy gładką, zaokrągloną spoinę, której nie trzeba już poddawać obróbce korygującej.

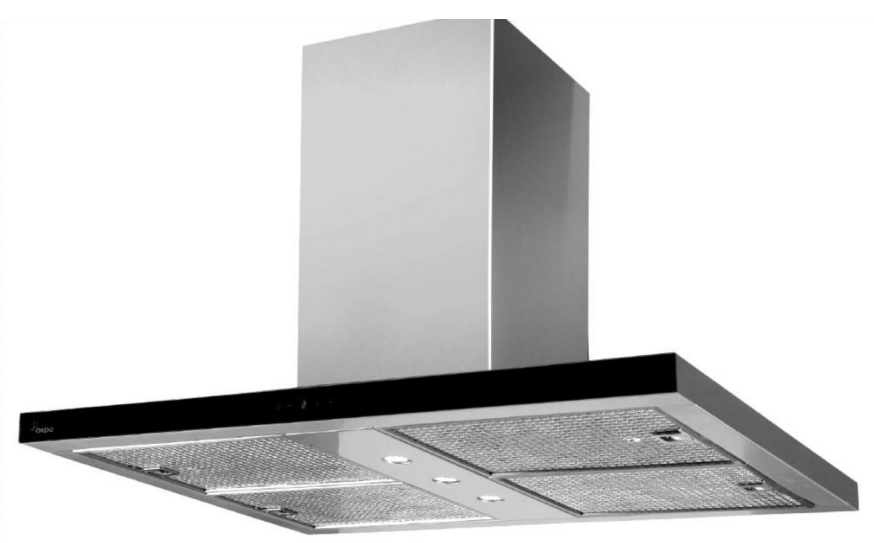

Rys. 1. Okap kuchenny z blachy Inox (źródło: katalog reklamowy firmy Akpo)

Fig. 1. Cooker hood with Inox sheet (source: catalog advertising company Akpo)

Do wymienionych zastosowań nadają się impulsowane lub pracujące $w$ trybie ciągłym lasery krystaliczne. Podczas spawania kondukcyjnego energia jest doprowadzana tylko przez przewodnik cieplny do przedmiotu obrabianego. Dlatego głębokość złącza wynosi zaledwie kilka dziesiętnych do jednego milimetra. Maksymalną głębokość spojenia ogranicza przewodność cieplna materiału. Szerokość spoiny zawsze jest większa od jej głębokości. Jeśli ciepło nie może dostatecznie szybko zostać odprowadzone, temperatura obróbki przekracza temperaturę parowania. Metal paruje, gwałtownie zwiększa się głębokość spawania i proces zamienia się w spawanie z głębokim wtopieniem, powodujące odkształcenia lub pęknięcia [8]. Do produkcji wyrobów AGD stosuje się spawanie laserowe, które jest w stanie zapewnić bardzo dobrą jakość spoin oraz (co jest nie mniej ważne) ich estetykę. Ocena wizualna jest bardzo ważna w przypadku wyrobów gospodarstwa domowego. 
Spoiny muszą być niewidoczne, gładkie, a jednocześnie trwałe. Użytkownik sprzętu AGD nie musi mieć świadomości jak zostały wyprodukowane urządzenia, koncentruje się on na ich funkcjonalności. Niedopuszczalna jest sytuacja, w której na obudowie pozostałyby np. odpryski spawalnicze. Rynek narzuca bardzo ostre kryteria jakościowe i producent, który ich nie spełni, nie ma szans na utrzymanie sprzedaży. W tym obszarze jakość bardzo ściśle wiąże się z ekonomią, zachowanie wysokich standardów wykonania jest konieczne i nie może wiązać się z wyższymi kosztami produkcji. Proces produkcji rozpoczyna się na etapie kupowania materiałów. Firma dokonuje zakupów u kwalifikowanych dostawców, którzy zapewniają materiały o doskonałej jakości potwierdzonej odpowiednimi atestami. Arkusze blachy są cięte laserem lub bardzo precyzyjnymi wykrawarkami, aby zapewnić powtarzalność i dokładność elementów. Obudowy okapów (rys. 2) wykonywane są z cienkich blach, o ściance nie przekraczającej 0,8 mm grubości, dlatego też niedokładne wykrawanie, czy gięcie nawet z minimalną odchyłką niemożliwe jest do poprawienia i dyskwalifikuje wyrób. Źle pocięty i wygięty materiał nadaje się do wyrzucenia. Stąd praca na urządzeniach najwyższej klasy daje wymierne oszczędności. Obniżanie kosztów produkcji wiąże się więc paradoksalnie ze stosowaniem maszyn i materiałów najwyższej jakości.

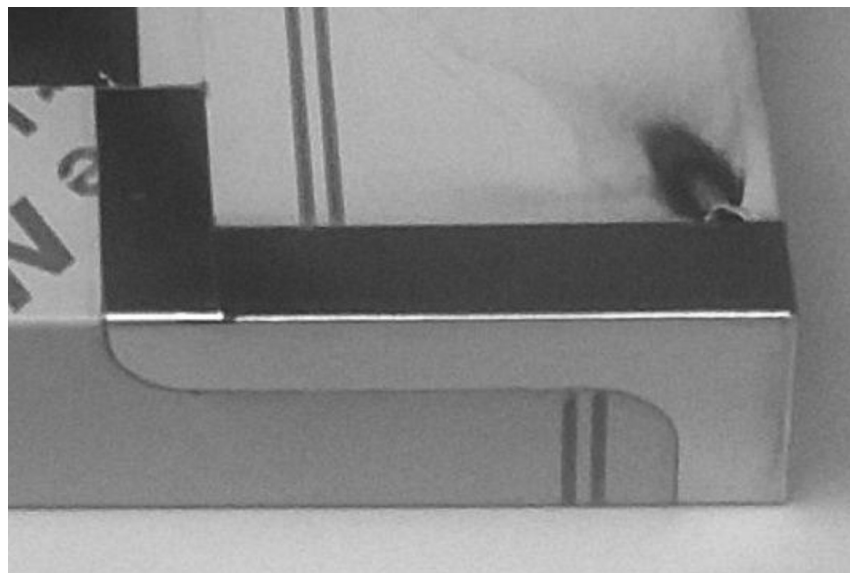

Rys. 2. Spawane naroże okapu (źródło: opracowanie własne) Fig. 2. Welded corner cooker hood (source: own case study)

Przed porysowaniem arkusze blach zabezpieczane są folią. Do procesu spawania stanowi to dodatkowe utrudnienie, ponieważ bardzo ważne jest odpowiednie odcięcie od łączonych krawędzi folii, a następnie oczyszczenie pozostałości kleju. Kolejnym ważnym etapem jest dokładne gięcie pociętych formatek, które musi zapewnić odchyłki wymiarowe nie większe niż 0,06-0,08 mm. Różnice w wymiarach większe niż $0,1 \mathrm{~mm}$ powodują niedokładności $\mathrm{w}$ procesie składania części okapu w oprzyrządowaniu i przy spawaniu laser nie jest w stanie wykonać prawidłowej spoiny.

Takie wady widoczne są podczas badań mikroskopowych oraz wizualnych. $\mathrm{Na}$ fotografii (rys. 3) przedstawiono niedokładność złącza, która powstała z błędu na etapie wykrawania. Z lewej strony widoczna jest bardzo wyraźna krawędź świadcząca o braku przetopu materiału, powstała w wyniku przesunięcia brzegów łączonych blach w stosunku do przebiegu osi promienia laserowego. W tym konkretnym przypadku podczas kontroli stwierdzono błąd wynikający z cięcia laserowego. Po przejściu wiązki na krawędzi blachy pozostał miejscowy grat o wymiarach nieprzekraczających $0,12 \mathrm{~mm}$.

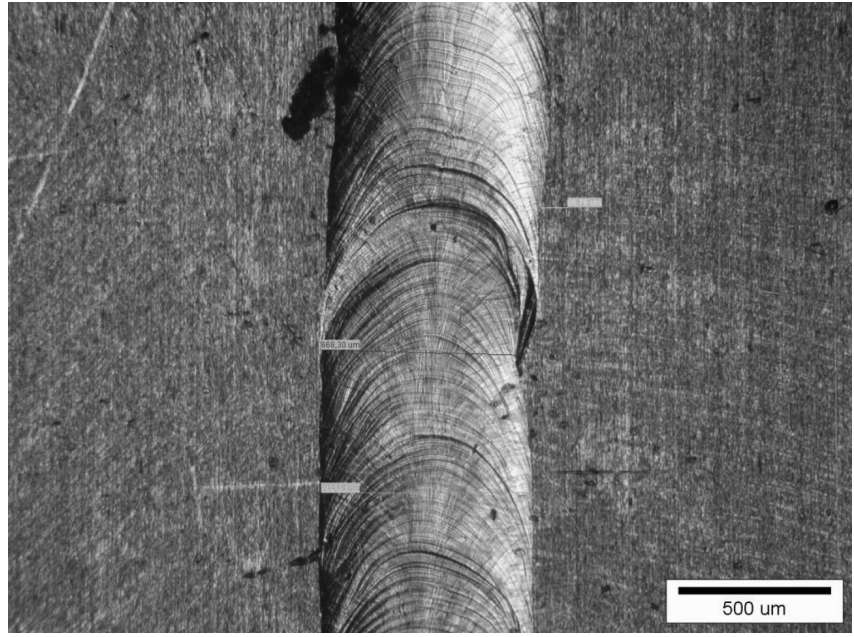

Rys. 3. Brak przetopu łączonych elementów (źródło: opracowanie własne)

Fig. 3. Lack of weld penetration connecting elements (source: own case study)

Prawidłowo wycięte i pogięte półfabrykaty podlegają spajaniu. Ogromną rolę odgrywa ustawienie parametrów lasera: moc, skupienie wiązki i prędkość poruszania się głowicy robota. Wiązka światła musi być skoncentrowana na małej powierzchni, dokładnie w osi spoiny. Celem jest uzyskanie jak najwęższej strefy wpływu ciepła. Nie mniej ważne jest uniknięcie występowania przebarwień spawalniczych. Ograniczenie wybarwień wokół spoiny osiąga się przez stosowanie dużej ilości gazu osłonowego, w ilościach niestosowanych dla zwykłych procesów spawalniczych. Precyzyjne dobranie parametrów spawania i gazu osłonowego powoduje, że wyrób natychmiast po spawaniu jest czysty i można go oddać do dalszego montażu. Proces technologiczny produkcji okapów jest okrojony do minimum. Pozostają tylko niezbędne operacje: wykrawanie, gięcie, spawanie, obróbka powierzchni, montaż podzespołów. Każdy z tych procesów cechuje się najwyższą dokładnością i gwarantuje wysoką jakość wyrobu końcowego.

Rozpatrywana w artykule firma stosuje spawanie laserowe tylko do okapów produkowanych z blachy nierdzewnej (rys. 4). Dla zachowania ich wysokiej

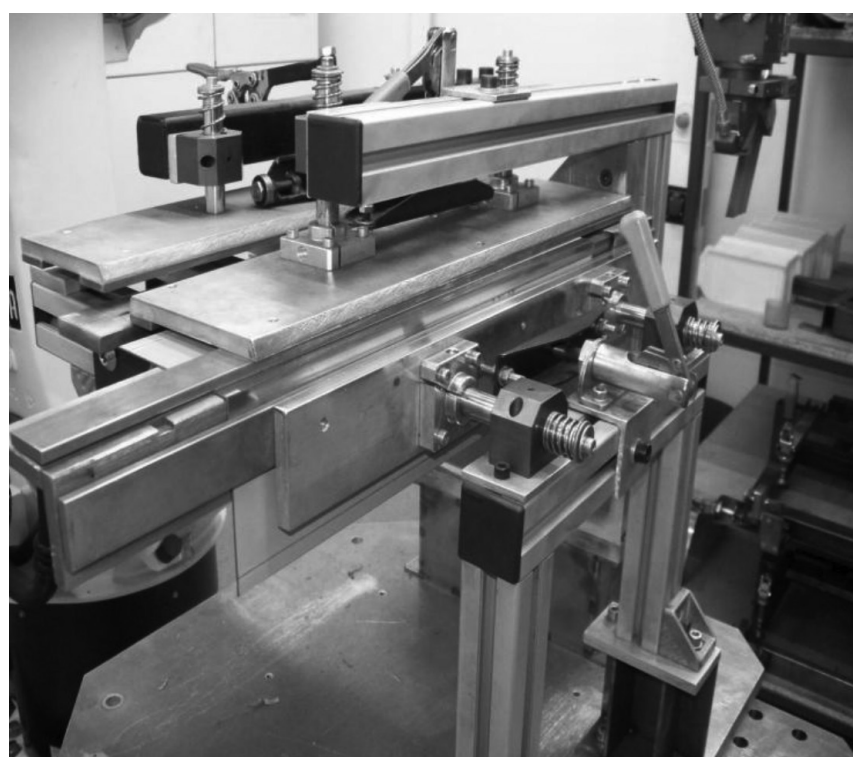

Rys. 4. Przykładowe oprzyrządowanie do spawania okapów (źródło: opracowanie własne)

Fig. 4. Example of equipment for welding cooker hood (source: own case study) 
jakości muszą one być oddzielone od blachy zwykłej, zarówno podczas składowania, jak i produkcji. Urządzenia, które miały styczność z blachą zwykłej jakości nie mogą być używane do blachy inox. Dlatego w firmie przeznaczone jest stanowisko robocze tylko do okapów z tych blach. Odpowiednie ustawienie urządzenia oraz jego stała parametryzacja ma także wpływ na obniżenie kosztów produkcji, ponieważ nie ma konieczności przezbrajania urządzeń, co ogranicza przestoje związane z czasem ustawczym. Nie od dzisiaj wiadomo, że najtańsza jest produkcja seryjna, powtarzalna i firmy dążą, w miarę możliwości, do obniżania kosztów tą drogą. Nie zawsze jest to możliwe w warunkach zmieniającego się rynku i preferencji odbiorców, jednak pewne etapy produkcji są niezmienne i tutaj można szukać optymalizacji kosztów. Jednym z takich etapów jest ustawie- nie parametrów lasera spawalniczego i zapewnienie wysokiej dokładności półfabrykatów na etapach cięcia i gięcia. Wyroby mogą mieć różne wzory, wymiary, ale niezmienny jest wymóg precyzji i ustawienie parametrów wiązki lasera, aby powierzchnia przebarwienia była możliwie najmniejsza, a spoina jak najczystsza, położona z równymi przetopami, co gwarantuje jej trwałość. Analizując właściwości techniczne i jakościowe produktów, należy uwzględnić aspekt ekonomiczny, gdyż rynek zweryfikuje, czy wyroby są konkurencyjne. Należy wyważyć proporcje między jakością i ceną. Produkt najwyższej jakości w konkurencyjnej cenie uzyska aprobatę konsumentów. Przedsiębiorstwo od lat produkuje okapy i ma bogate doświadczenie zarówno co do zachowania jakości wyrobów, jak i utrzymania korzystnych dla obu stron cen.

\section{Podsumowanie}

Spawanie laserowe wykorzystuje wiązkę o bardzo dużej gęstości energii, co sprzyja uzyskaniu złączy o małych szerokościach, wąskiej SWC i bardzo gładkim licu. Głównymi zaletami tego procesu są:

- wysoka precyzja, jakość i estetyka złączy spawanych, bez konieczności oczyszczania spoin;

- bardzo duże prędkości procesu, który jest w pełni zautomatyzowany (możliwość monitorowania i regulowania dopływu energii w czasie rzeczywistym).

Największym utrudnieniem w spawaniu laserowym wyrobów AGD z blach cienkościennych jest konieczność zachowania dużej dokładności na etapach przygotowania produkcji, takich jak cięcie i gięcie elementów składowych. Istotną wadą jest nieopłacalność w przypadku produkcji jednostkowej.

Należy podkreślić, że spawanie laserowe jest najefyktewniejszą a czasami jedyną technologią dającą się zastosować w produkcji wyrobów z cienkościennych blach nierdzewnych.

\section{Literatura}

[1] Ferenc K.: Spawalnictwo. WNT. Warszawa, 2007.

[2] Klimpel A.: Spawanie, zgrzewanie i cięcie metali. WNT. Warszawa, 1999.

[3] Chmielewski T.: Projektowanie procesów technologicznych - spawalnictwo. OWPW. Warszawa, 2013

[4] Poradnik inżyniera. Spawalnictwo. WNT. Warszawa, 2005

[5] Tasak E.: Metalurgia spawania. Wyd. JAK. Kraków, 2008.

[6] Sałaciński T.: Inżynieria jakości w technikach wytwarzania. OWPW. Warszawa, 2016

[7] Pilarczyk J., Stano S., Banasik M., Dworak J.: Wykorzystanie technik laserowych do spawania elementów o małych wymiarach w Centrum Laserowym Instytutu Spawalnictwa. Gliwice, 2011. yadda.icm.edu.pl.
[8] Spawanie stali nierdzewnych, wydanie drugie, kwiecień 2002, Materiały i Zastosowania. www.worldstainless.org/Files/issf/non-image-files/ PDF/Euro_Inox/Brochure Weldability_PL.pdf

[9] Chiniewicz W.: Metody spawania stali nierdzewnych. www.nierdzewka. com/userfiles/download/metody_spawania_stali_nierdzewnych

[10] Kimmel R.: Laserschweißen in der Blechfertigung. TRUMPF Laser und Systemtechnik GmbH.

[11] Chrobak G.: Spawanie laserowe blach. Materiały szkoleniowe TRUMPF TruLaser Robot.

[12] www.pl.trumpf.com/pl/produkty/technika-laserowa/aplikacje/obszaryzastosowan/spawanie-laserowe.html 